\title{
Perancangan Website E-Commerce Penjualan Ikan Cupang
}

\author{
Vira Kristianingrum ${ }^{1}$, Muhammad Fizkry Yusuf Al-Fadillah ${ }^{2}$
}

${ }^{1}$ Program Studi Informatika, Universitas Singaperbangsa Karawang

${ }^{2}$ Program Studi Informatika, Universitas Singaperbangsa Karawang

\begin{tabular}{l}
\hline ARTICLE INFORMATION \\
\hline ISSN: $2579-7204$ (Online) \\
ISSN: 0216-4132 (Print) \\
DOI: $10.26487 /$ jbmi.v18i3.19538 \\
\hline SUBMISSION TRACK \\
\hline Received: 17, January, 2022 \\
Final Revision: 10, February, 2022 \\
Available Online: 24 February, 2022 \\
\hline KATA KUNCI
\end{tabular}

E-Commerce; Penjualan Online; Ikan Cupang; UML; MySql; Xampp.

\begin{abstract}
ABSTRAK
E-Commerce adalah transaksi penjualan dan pembelian yang melalui sistem elektronik yang tersambung oleh internet. Dalam beberapa tahun terakhir, penjualan online berkembang pesat sejalan seiringnya perkembangan teknologi saat ini yang membuat kita memerlukan metode atau sistem dalam meningkatkan produktivitas dan efisiensi untuk menyampaikan informasi tentang penjualan produk di situs web, mengingat kecepatan dalam pemrosesan informasi menjadi satu hal yang sangat penting, terutama di dunia bisnis dan perdagangan. Dari banyaknya jenis ikan hias, yang menarik perhatian dan cukup mudah untuk dipelihara dan mempunyai banyak peminat atau kolektor nya adalah Ikan cupang. Tapi tidak banyak yang menjual nya secara online. Oleh karena itu, ikan cupang bisa kita jadikan bisnis online supaya mempermudah pembeli yang hanya menunggu dirumah. Metode yang diguankan adalah UML, ERD, dan MySQL. Hasil analisis pada Perancangan Website Penjualan Ikan Cupang ini dibuat dengan metode pemodelan UML (Unified Modelling Language), ERD (Entity Relation Diagram) dan MySQL sebagai penyimpanan database yang dikoneksikan dengan Xampp. Lalu dari perancangan User Interface, menghasilkan halaman admin yang hanya dapat di akses dan dikelola oleh admin. Diantaranya ada menu halaman utama admin, menu customers orders, product, data customers, dan inbox.
\end{abstract}

\begin{tabular}{|c|c|}
\hline KEYWORD & ABSTRACT \\
\hline $\begin{array}{l}\text { E-Commerce; E-Business; Betta Fish; } \\
\text { UML; MySql; Xampp. }\end{array}$ & \multirow{5}{*}{$\begin{array}{l}\text { E-Commerce is a sale and purchase transaction } \\
\text { through an electronic system that is connected by the } \\
\text { internet. In recent years, online sales have developed } \\
\text { rapidly in line with current technological } \\
\text { developments that make us need a method or system } \\
\text { that can increase productivity and efficiency in } \\
\text { delivering information about product sales on a web } \\
\text { site, given the speed in processing information } \\
\text { becomes a very important thing, especially in the } \\
\text { world of business and commerce. One type of } \\
\text { ornamental fish that is quite easy to maintain and has } \\
\text { many enthusiasts or collectors is betta fish. But not } \\
\text { many sell them online. Therefore, we can make betta } \\
\text { fish online business to make it easier for buyers who } \\
\text { are just waiting at home. The methods used are UML, }\end{array}$} \\
\hline CORRESPONDENCE & \\
\hline & \\
\hline & \\
\hline a.ac. & \\
\hline
\end{tabular}


$E R D$, and MySQL. The results of the analysis on the Betta Fish Sales Website Design were made using UML (Unified Modeling Language), ERD (Entity Relation Diagram) and MySQL as storage databases that are connected to Xampp. Then from the User Interface design, it produces an admin page that can only be accessed and managed by the admin. Among them are the admin main page menu, customer orders menu, product, customer data, and inbox.

\section{PENDAHULUAN}

Perkembangan zaman saat ini di bidang teknologi semakin pesat. Setiap harinya teknologi terus berkembang yang menuntut kita untuk dapat berkompetensi dengan menguasai ilmu pengetahuan dalam bidang teknologi dan juga mengerti kalau komputer itu sangat penting untuk membantu pekerjaan. Konsumen semakin banyak menggunakan smartphone, tablet, dan perangkat seluler lainnya untuk melakukan penelitian dan pembelian produk dan layanan yang mereka minati saat mereka di dalam toko, menonton TV, atau menggunakan kios. Faktanya, lebih dari setengah konsumen secara teratur menggunakan dua atau lebih perangkat digital pada satu waktu. Teknologi banyak digunakan untuk menjadi media periklanan dan penambah wawasan di kemas didalam website yang saat ini memiliki peran penting pada penyampaian dan memberi informasi. Website juga menjadi media yang sangat membantu untuk mengenalkan kepada masyarakat luas tentang produk yang ingin di pasarkan lalu menjadi wadah transaksi penjualan dan pembelian dalam bentuk barang atau jasa dan informasi yang disebut dengan e-commerce (Salehi, 2012). Menurut Rachmat (2019), E-commerce memungkinkan suatu perusahaan untuk berhubungan dengan sistem pemrosesan data internal dan eksternal secara lebih efisien dan fleksibel. Salah satu contoh dari $e$ commerce misalnya pembelian barang secara online dan pembelian hewan khusus yang memang di perbolehkan di perjual belikan secara online. Tujuan implementasi $e$ commerce adalah mendukung efisiensi dan integritas pengolaan data sumber daya manusia, keuangan, supply chain management atau logistic management. Selain itu juga berfungsi sebagai sarana komunikasi dan informasi bagi public dan stakeholder lainnya dengan berbasiskan internet, sistem ini dapat diakses di mana saja sesuai dengan hak akses yang telah ditentukan (M. Niranjanamurthy, 2013).

E-commerce atau perdagangan elektronik, yaitu hanya bisa diakses dengan jaringan internet. Setiap perusahaan atau individu yang ingin melakukan transaksi jual beli barang atau layanan jasa secara daring, mereka terlibat dalam e-commerce. Berbelanja daring menjadi pilihan untuk mempromosikan baramg terbaik, ketersediaan dan kenyamanan yang tidak memiliki minim waktu dan ruang. Kenyamanan adalah faktor penting dalam e-commerce. Pelanggan dapat mengambil manfaat dari yang harganya lebih rendah, pencarian lebih cepat, lebih mudah untuk mecari perbandingan dan pilihannya lebih banyak. Ikan cupang berpopulasi di air tawar yang spesies ikan ini biasanya dipelihara sebagai ikan hias dan ikan aduan. Ikan cupang menjadi ikan hias yang cukup popular di Indonesia. Habitat spesies ikan ini berasal dari perairan yang tersebar di negara dari Asia Negara, yaitu Thailand, Indonesia, Malaysia, Vietnam. Tampilan dari ikan cupang yang indah dan menarik menjadi salah satu penarik perhatian bagi kalangan pecinta ikan hias maupun ikan Kelebihan dari ikan cupang 
ialah, mereka dapat bertahan hidup dalam waktu yang cukup lama bahkan jika volume air sedikit dan tanpa adanya oksigen atau sirkulasi udara mereka masih mampu untuk bertahan hidup. Hal ini dikarenakan memiliki alat bernafas yang disebut labyrinth. Posisinya di dalam rongga insang sebelah atas (Megumi, 2019).

Ikan cupang bisa di jadikan bisnis online supaya bisnis ini dapat meningkat dan bisa meraih pasar global. Pentingnya dilakukan perancangan e-commerce penjualan ikan cupang dikarenakan, masih jarang sekali penjualan ikan cupang secara online. Padahal ikan cupang merupakan ikan yang paling banyak diminati oleh banyak kalangan. oleh karena itu dengan adanya perancangan e-commerce ini diharapkan para peminat ikan cupang dapat melaksanakan jual beli secara mudah. Seperti penelitian terdahulu yaitu menurut Putri (2019), sistem e-commerce tersebut nantinya akan dikembangkan menggunakan metode waterfall meliputi Requirements Analysis, Design, Implementation, Testing, Maintenance system, system ini akan dibangun menggunakan tool seperti XAMPP, database MySQL dan PHP sebagai bahasa pemrograman, bahasa pemrograman PHP merupakan bahasa pemrograman yang tidak berbayar (open source) yang dapat digunakan oleh siapa saja. PHP juga dapat terintegrasi dengan baik pada database MySQL, aplikasi web berbasis PHP tergolong aman dibandingkan dengan aplikasi web yang dikembangkan menggunakan bahasa pemrograman lain.

\section{TINJAUAN PUSTAKA}

\section{Diagram Use Case}

Use case atau diagram use case merupakan pemodelan untuk kelakuan (behavior) sistem informasi yang akan dibuat. Use case mendeskripsikan sebuah interaksi antara satu atau lebih aktor dengan sistem informasi yang akan dibuat. Secara kasar, use case digunakan untuk mengetahui fungsi apa saja yang ada di dalam sebuah sistem informasi dan siapa saja yang berhak menggunakan fungsi-fungsi itu. Menurut Esseba (2018), Sebuah use case juga dapat diketahui interaksi apa saja yang akan dijalankan oleh sistem yang dibuat.

\section{Activity Diagram}

Diagram aktivitas atau activity diagram menggambarkan workflow (aliran kerja) atau aktivitas dari sebuah sebuah sistem atau proses bisnis atau menu yang ada pada perangkat lunak. Yang perlu di perhatikan disini adalah bahwa diagram aktivitas menggambarkan aktivitas sistem bukan apa yang dilakukan aktor, jadi aktivitas yang dapat dilakukan oleh sistem. Activity diagram menunjukkan logika kondisional untuk urutan aktivitas sistem yang diperlukan untuk menyelesaikan suatu proses bisnis. Aktivitas individu bisa saja manual atau otomatis. Selanjutnya, setiap kegiatan adalah tanggung jawab unit organisasi tertentu (Valacich \& George, 2016). Menurut Peneliti (Tilley \& Rosenblatt, 2016), activity diagram adalah diagram yang menyerupai obrolan bagan alur horisontal yang menunjukkan tindakan dan peristiwa saat terjadi. Activity diagram menunjukkan urutan tindakan yang dilakukan dan mengidentifikasi hasilnya. Sedangkan menurut peneliti (Seidl et al., 2015), activity diagram adalah diagram yang 
menawarkan mekanisme aliran kontrol serta mekanisme aliran data yang mengkoordinasikan aksi yang membentuk suatu aktivitas. (Denni, Wixom, \& Tegarden, 2015) mengungkapkan bahwa activity diagram adalah diagram yang menggambarkan aktivitas utama dan hubungan antara aktivitas dalam suatu proses. Peneliti lainnya (Wazlawick, 2014) menjelaskan, activity diagram dapat menspesifikasikan perbedaan antara aktivitas yang dilakukan oleh aktor yang berbeda.

\section{Sequence Diagram}

diagram sekuen menggambarkan kelakuan objek pada use case dengan mendeskripsikan waktu hidup objek dengan massage yang dikirimkan dan diterima antar objek. Oleh karena itu untuk menggambarkan diagram sekuen maka harus diketahui objek-objek yang terlibat dalam sebuah use case beserta metode-metode yang dimiliki kelas yang diinstansiasi menjadi objek itu. Membuat diagram sekuen juga dibutuhkan untuk melihat skenario yang ada pada use case. Banyaknya diagram sekuen yang harus digambar adalah minimal sebanyak pendefinisian use case yang memiliki proses sendiri atau yang penting semua use case yang telah didefinisikan interaksi jalannya pesan sudah dicakup dalam diagram sekuen sehingga semakin banyak use case yang didefinisikan maka diagram sekuen yang harus dibuat juga semakin banayak. Menurut peneliti (Valacich \& George, 2016), sequence diagram menggambarkan interaksi antar objek selama jangka waktu tertentu. Karena pola interaksi bervariasi dari satu use case ke yang lain, setiap sequence diagram hanya menunjukkan interaksi yang berkaitan dengan use case yang spesifik. Sedangkan menurut (Unhelkar, 2018), sequence diagram mewakili interaksi terperinci antara aktor dan sistem atau antara objek yang berkolaborasi dalam blok waktu tertentu. (Tilley \& Rosenblatt, 2016) mengemukakan bahwa sequence diagram menunjukkan waktu interaksi antara objek ketika berlangsung. Menurut peneliti (Seidl et al., 2015).

\section{Class Diagram}

diagram kelas atau class diagram menggambarkan struktur sistem dari segi pendefinisian kelas-kelas yang akan dibuat untuk membangun sistem. Kelas memiliki apa yang disebut atribut dan method atau operasi. Atribut merupakan variabel yang dimiliki oleh suatu kelas. Operasi atau method adalah fungsi-fungsi yang dimiliki suatu kelas.

\section{METODE PENELITIAN}

Bagaimana sebuah sistem dapat berjalan, dilakukan analisa terlebih dahulu dengan menggunakan metode pemodelan Unifed Modelling Language (UML) sebagai gambaran urutan dan proses yang berjalan saat ini. Yaitu:

\section{Use Case Diagram}


Use case diagram adalah serangkaian aksi, layanan dan fungsi yang perlu dilakukan dalam sebuah sistem. Sistem disini yaitu sesuatu yang sedang dirancang atau dikembangkan seperti situs web. Aktor disini adalah orang atau entitas yang berperan untuk menentukan aksi dalam sistem tersebut. (Johan, 2013).

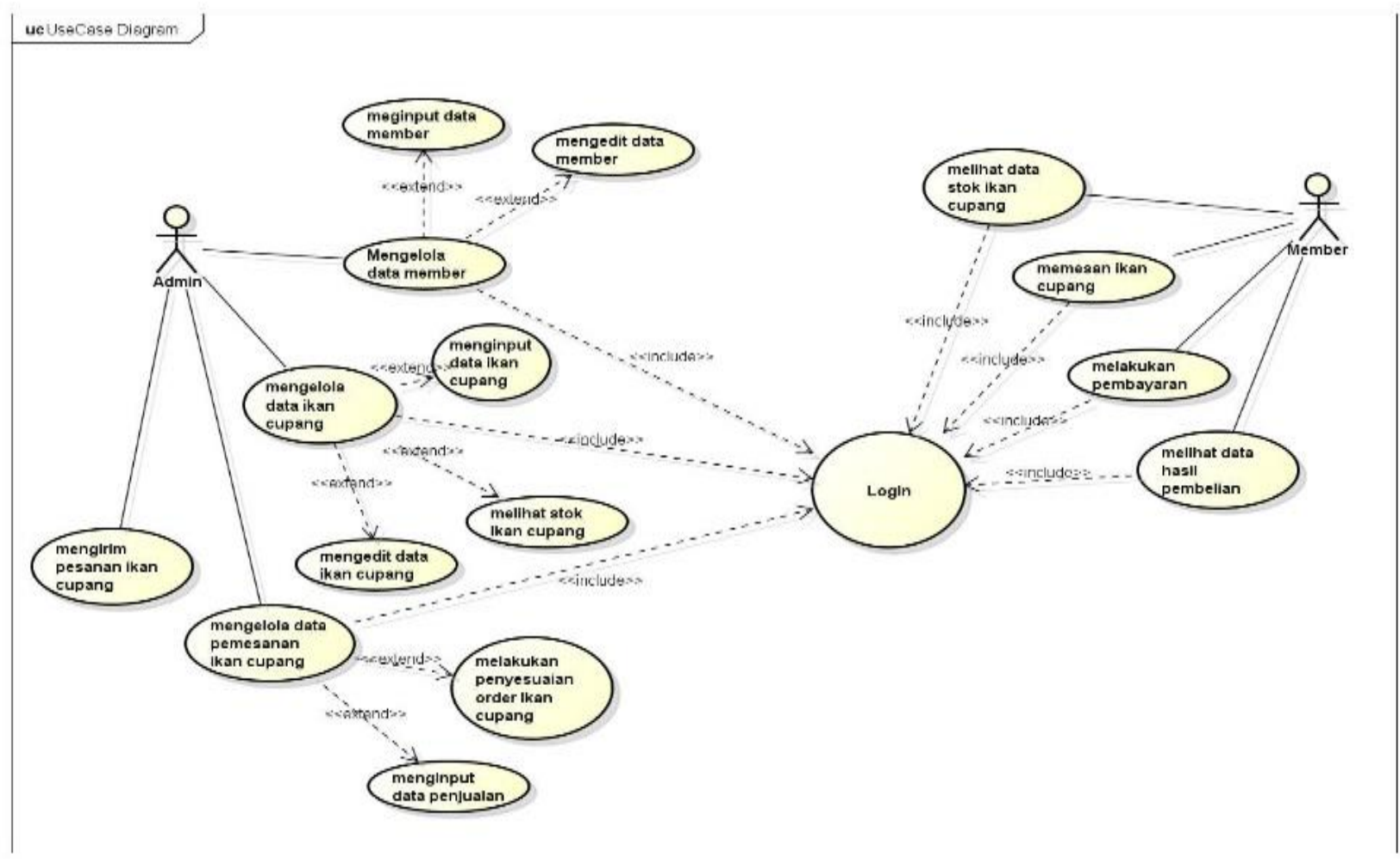

\section{Gambar 1. Use Case Diagram}

\section{$\underline{\text { Member }}$}

Langkah pertama untuk melihat data ikan cupang, memesan, lalu melakukan transaksi pembayaran dan juga melihat hasil pembelian ikan cupang tersebut, diharuskan registrasi dengan mengisi data yang diperlukan, lalu login untuk memastikan bahwa akun sudah terdaftar.

\section{$\underline{\text { Admin }}$}

Untuk memiliki akses mengelola data ikan cupang, mengelola data member, mengelola data pemesanan ikan, serta mengirim pesanan ikan cupang, admin harus memasukan username dan password lalu login ke dalam website. Selain itu, admin berhak menginput data penjualan dan melakukan penyesuaian order ikan.

\section{Activity Diagram}

Definisi dari activity diagram atau bisa juga disebut diagram alur berorientasi obyek, yaitu diagram UML yang fokusnya kepada eksekusi dan aliran perilaku sistem. 
Activity Diagram digunakan untuk melakukan pemodelan proses dan alur kerja. Dengan kata sederhana, digunakan untuk diagram aktivitas yang menggambarkan aliran eksekusi antara beberapa aktivitas. Activity Diagram menggambarkan aliran kontrol dari titik awal ke titik akhir yang menunjukkan berbagai jalur keputusan yang ada saat aktivitas dijalankan. Digunakan dalam pemodelan bisnis dan proses di mana penggunaan utama mereka adalah untuk menggambarkan aspek dinamis dari suatu sistem.

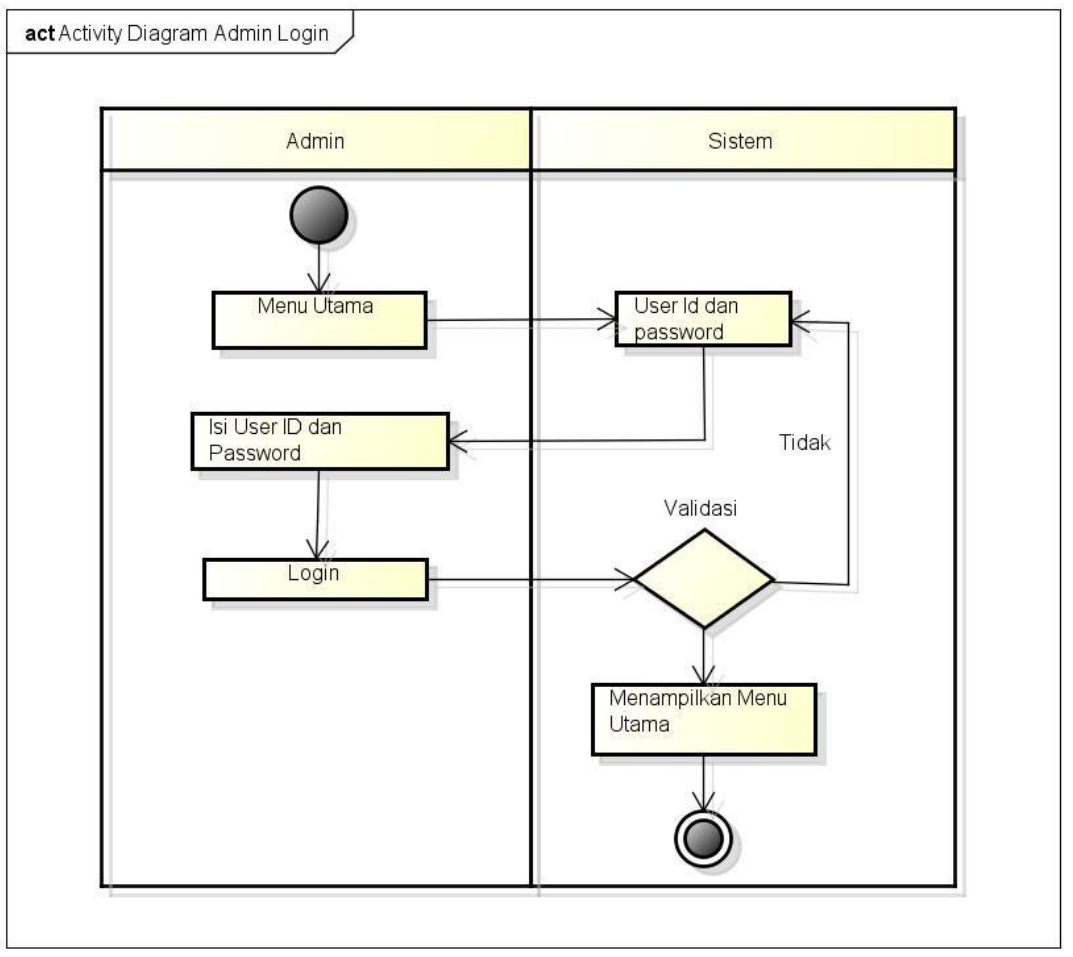

powered by Astahas

Gambar 2. Activity Diagram Admin Login 


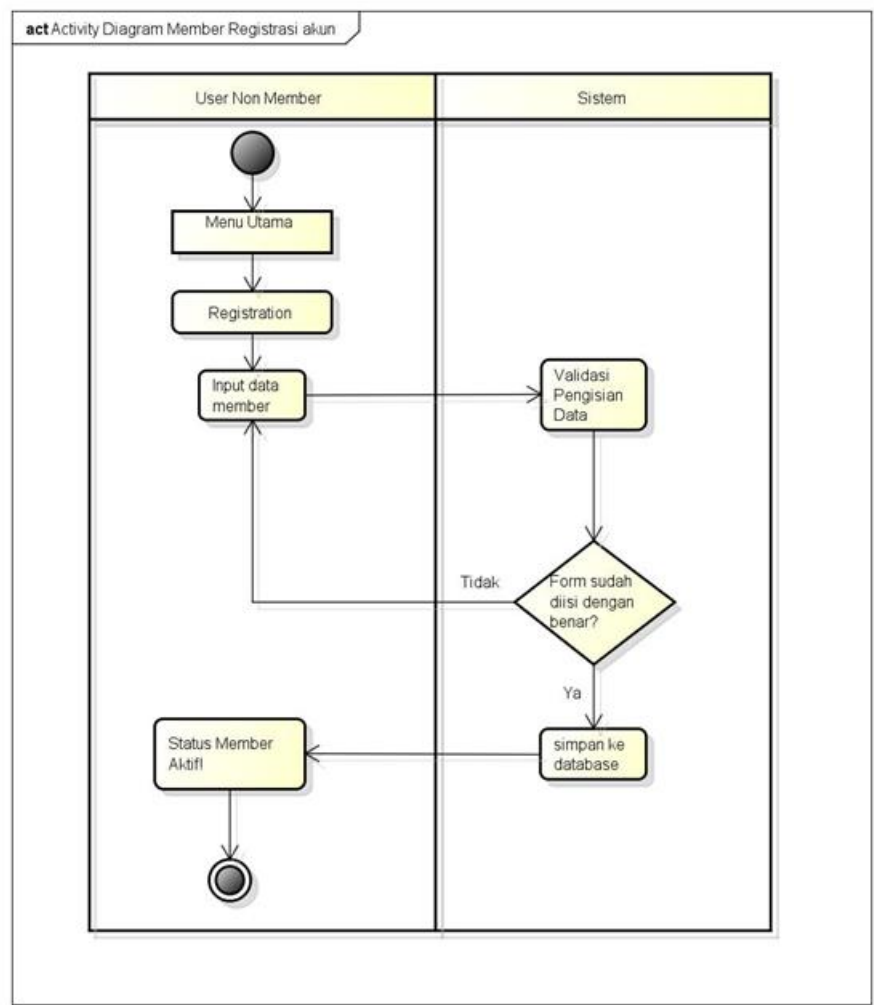

Gambar 3. Activity Diagram Member Registrasi Akun

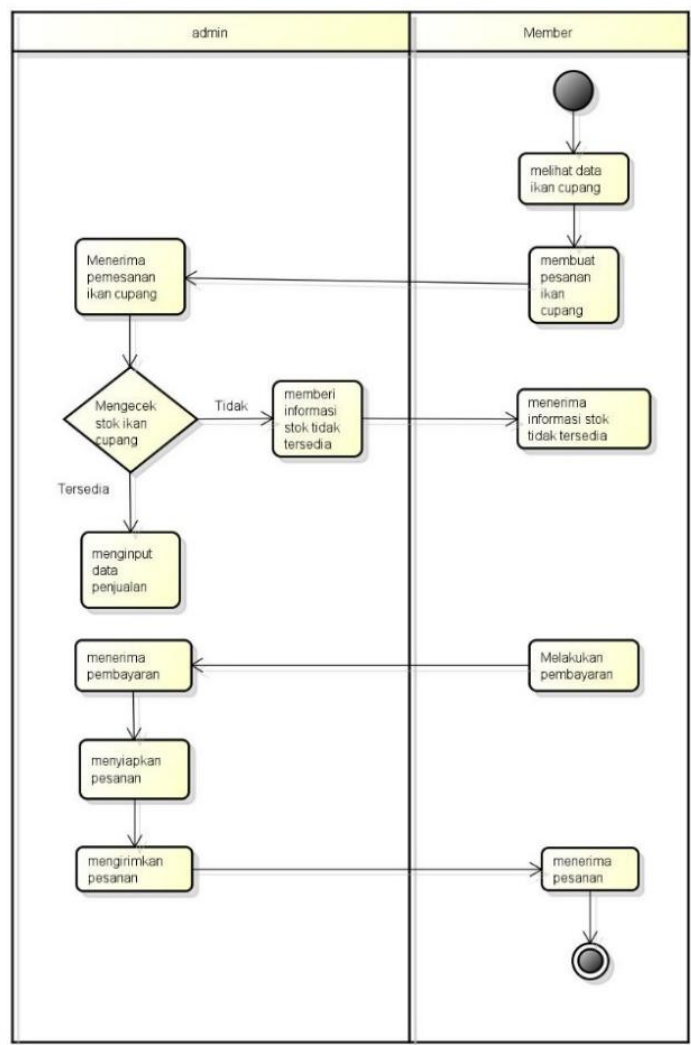

Gambar 4. Activity Diagram Pembelian Ikan Cupang 


\section{Sequence Diagram}

Sequence diagram menggambarkan interaksi antar kelas dalam hal pertukaran pesan dari waktu ke waktu. Diagram ini memvisualisasikan dan memvalidasi skenario waktu berjalan yang baik dengan menggunakan garis vertkal untuk mewakili waktu pesan yang dikirim (Hasugian, 2018).

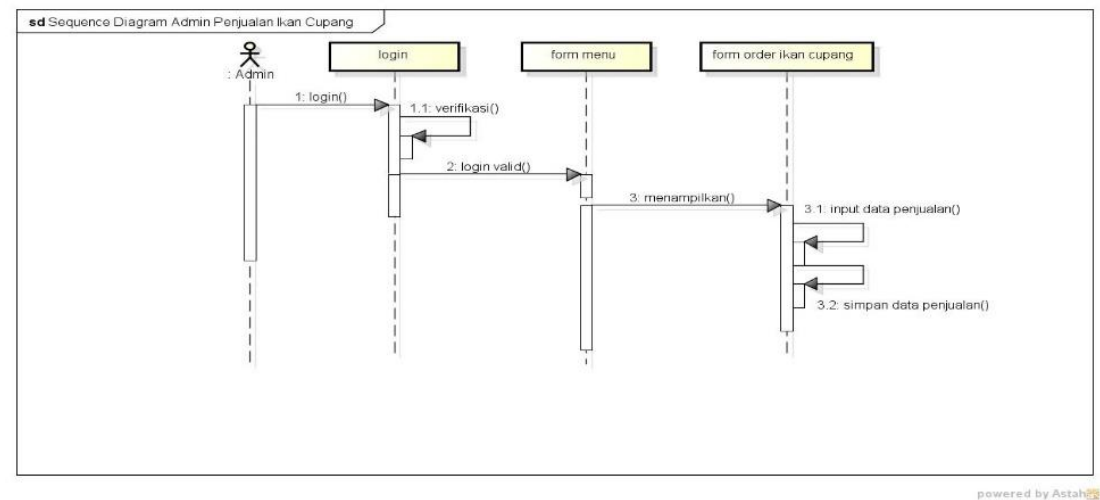

\section{Gambar 5. Sequence Diagram Admin Penjualan Ikan Cupang}

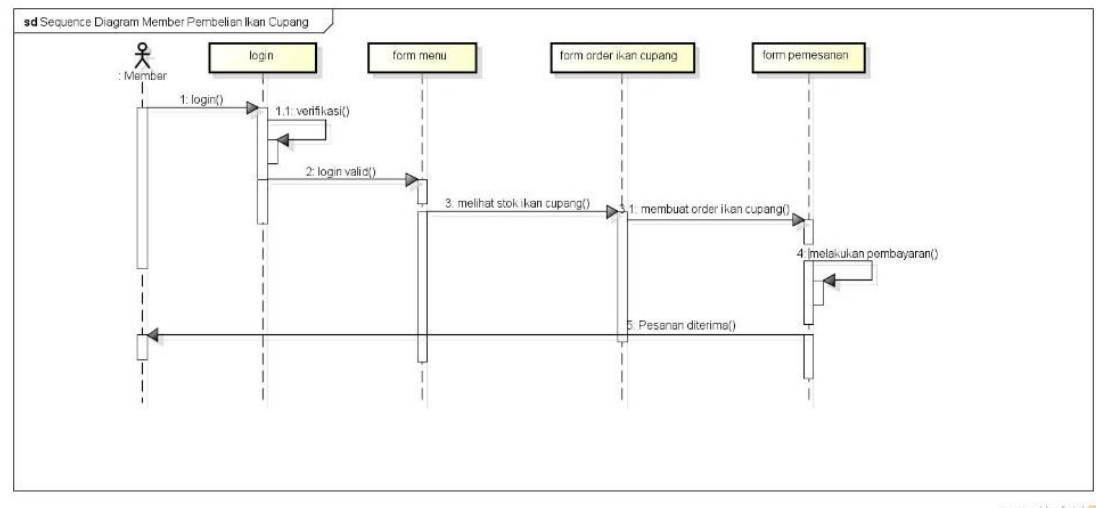

\section{Gambar 6. Sequence Diagram Member Pembelian Ikan Cupang}

\section{Class Diagram}

Class diagram adalah cara yang rapih untuk memvisualisasikan kelas-kelas di sistem yang sedang dirancang. Class diagram digunakan untuk menampilkan objek yang berbeda dari suatu sistem, atribut, operasi dan hubungan atau relasi antar kelas. Class diagram menggambarkan struktur dan deskripsi class, packed dan objek beserta hubungan satu sama lain seperti containment, pewarisan, asosiasi dan lainnya. 


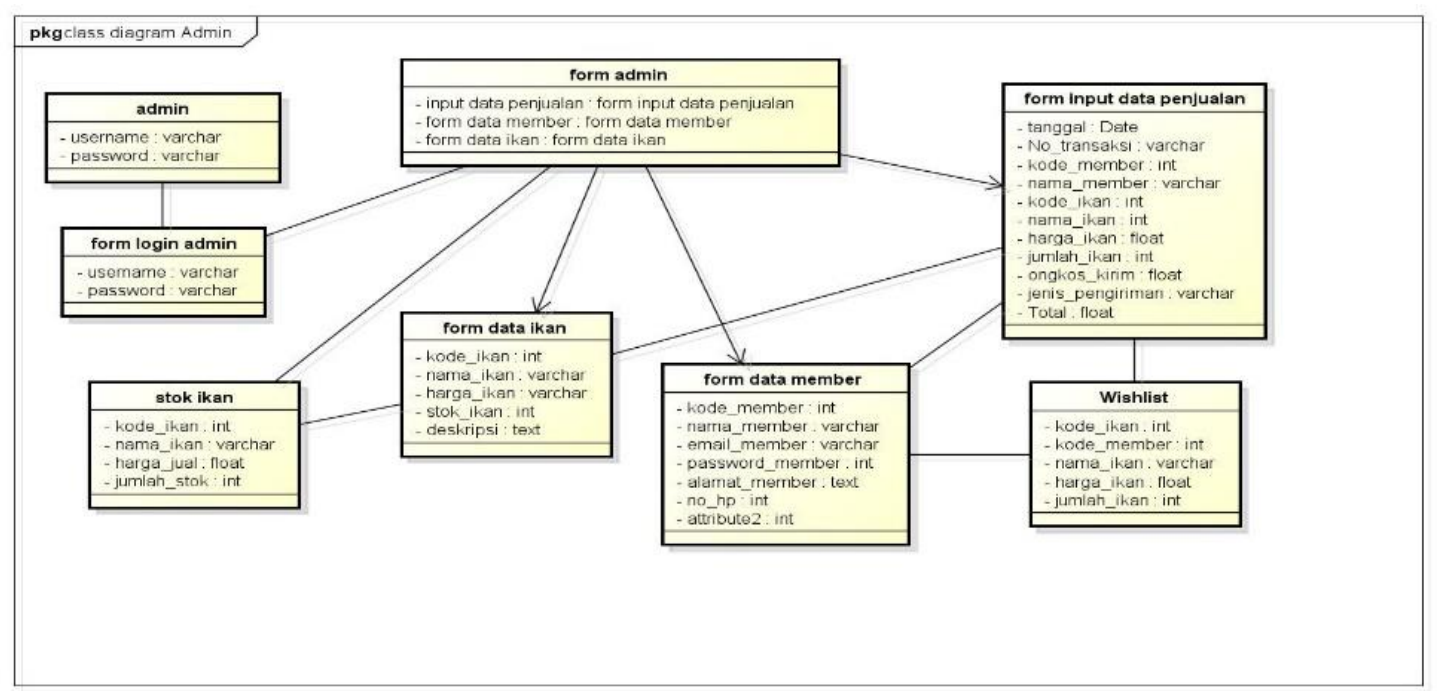

\section{Gambar 7. Class Diagram}

\section{Deployment Diagram}

Deployment diagram adalah jenis diagram yang menentukan perangkat keras fisik yang akan dieksekusi oleh sistem perangkat lunak. Ini juga menenetukan bagaimana perangkat lunak digunakan pada perangkat keras yang mendasarinya. Deployment diagram memetakan potongan perangkat lunak ke sistem yang akan menjalankan sebuah perangkat (Rachman, 2017).

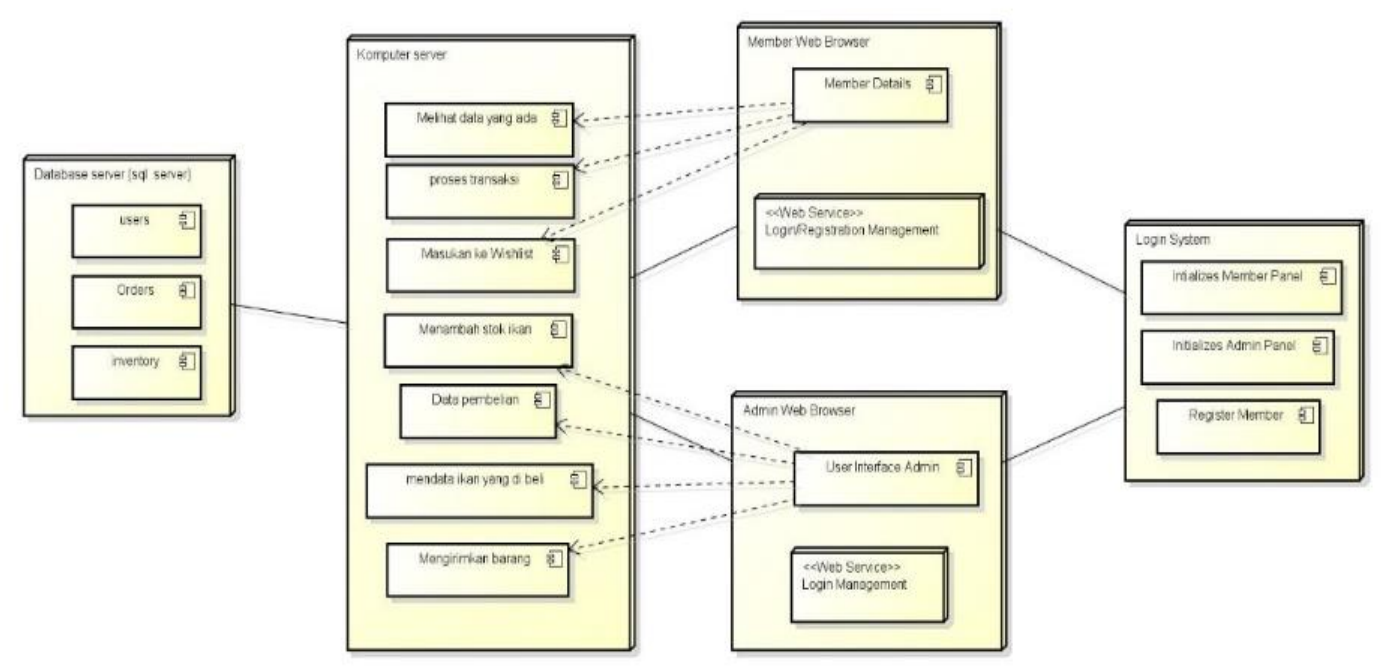

\section{Gambar 8. Deployment Diagram}

6. Entity Relationship Diagram (ERD)

ERD (Entity Relationship Diagram) atau pemodelan hubungan entitas adalah pemodelan data yang secara grafis menggambarkan entitas sistem informasi dan 
hubungan atau relasi antara entitas tersebut. ERD juga sebagai model data konseptual dan representasional yang digunakan untuk mewakili struktur kerangka entitas. ERD menggunakan teknik pemodelan data yang dapat membantu menentukan proses bisnis dan berfungsi sebagai dasar basis data relasional.

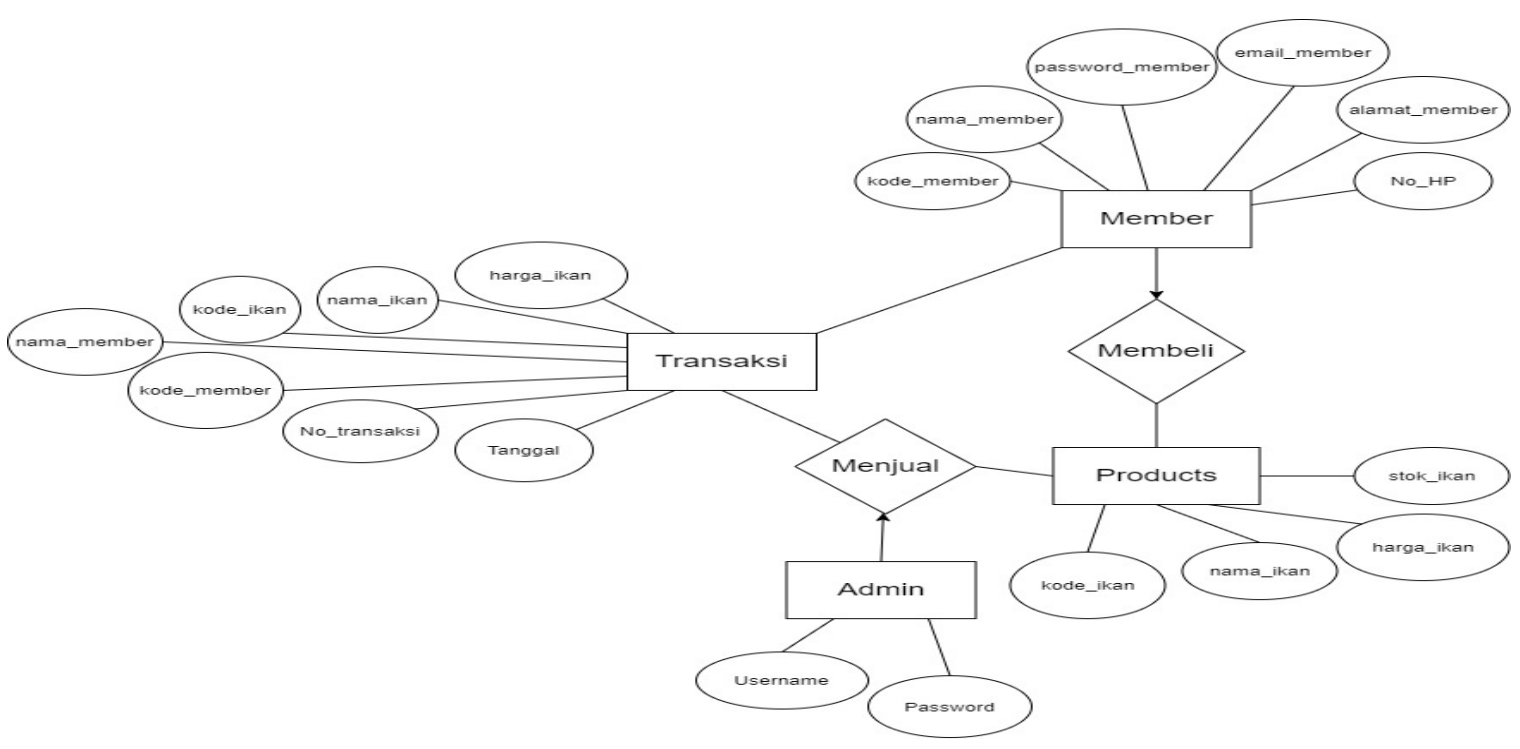

Gambar 8. ERD

\section{HASIL DAN DISKUSI}

\section{Deskripsi Sistem}

Pengelompokan komponen dan elemen untuk mendapatkan hasil dari tujuan yang teah dirancang yaitu menjadi sebuah sistem. Sistem perancangan website ini dibangun dengan PHP dan XAMPP MySQL untuk penyimpanan database. Dari hasil rancangan yang telah dibangun akan menampilkan output dalam bentuk program website. Berikut adalah hasil dari output dari program yang telah dirancang:

\section{Tampilan Halaman Utama Admin}

Setelah melakukan proses login admin, yaitu memasukkan username dan password nya, maka akan menampilkan halaman admin seperti dibawah ini. Pada halaman ini, admin dapat mengakses ke tampilan lainnya dengan memilih di bagian menu. 


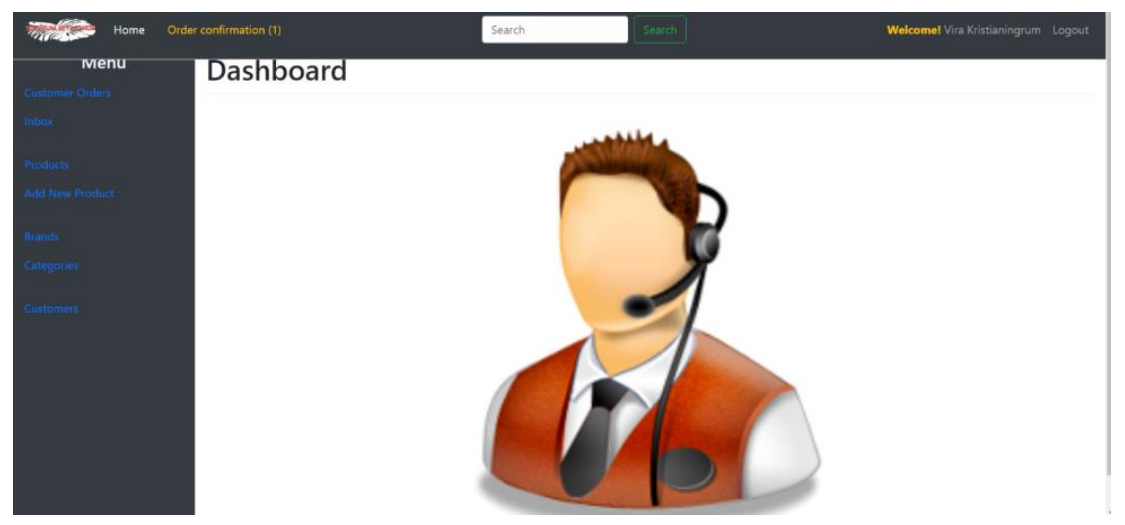

Gambar 9. Screenshot Halaman Utama Admin

2. Tampilan Halaman Menu Customer Orders

Di dalam tampilan customer orders, menampilkan daftar transaksi oleh customer yang telah melakukan pesanan ikan cupang

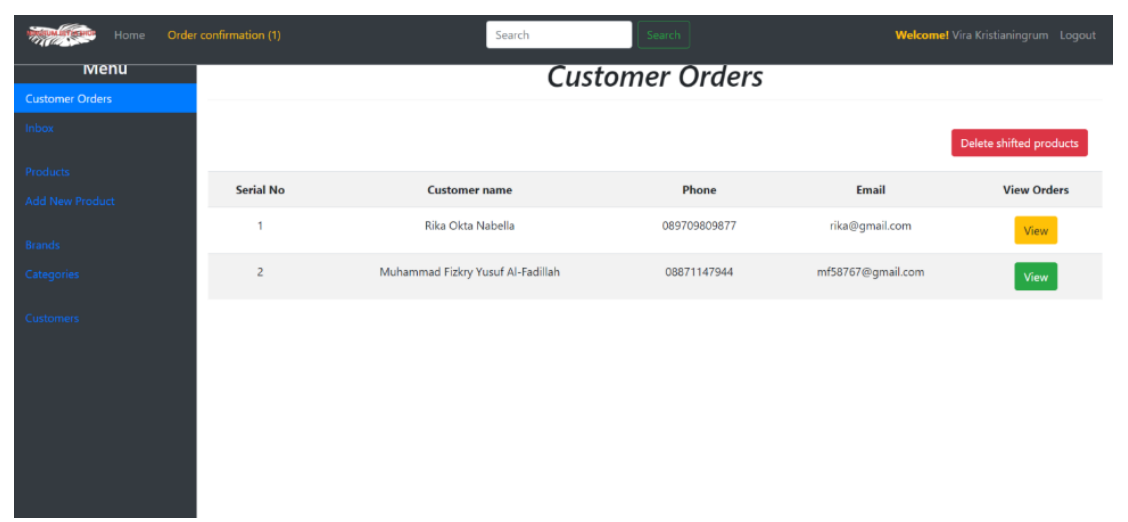

Gambar 10. Screenshot Halaman Customer Orders

3. Tampilan Halaman Menu Produk

Pada halaman ini menampilkan sejumlah data produk ikan cupang yang telah di tambahkan sebelumnya oleh admin dan dapat diubah atau dihapus. Lalu akan ditampilkan pada menu halaman utama yang akan di akses oleh customer. 


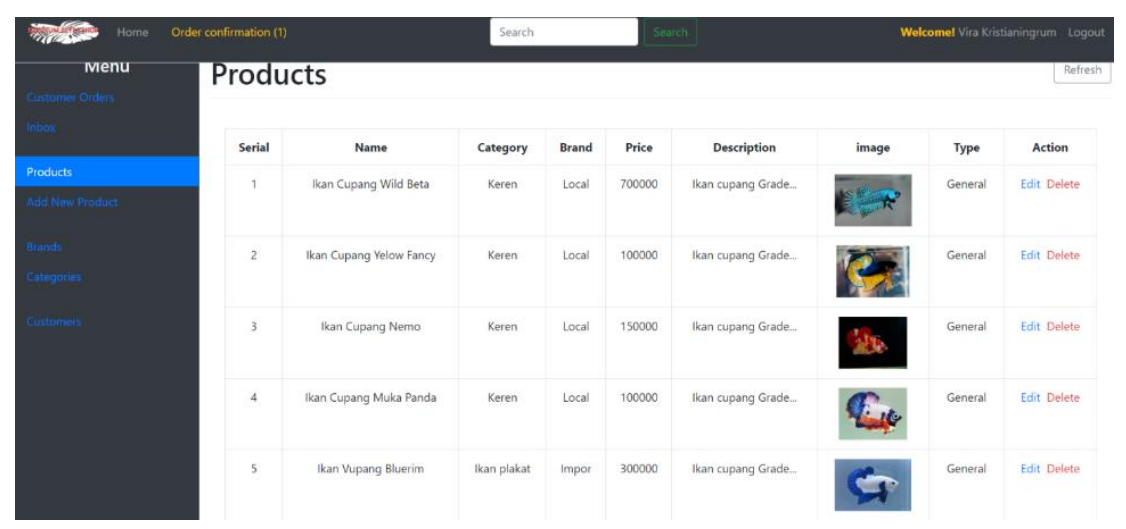

\section{Gambar 11. Screenshot Halaman Produk Ikan Cupang}

4. Tampilan Halaman Menu Data Customers

Halaman yang hanya dapat di akses oleh admin ini berisi data customers yang telah melakukan registrasi.

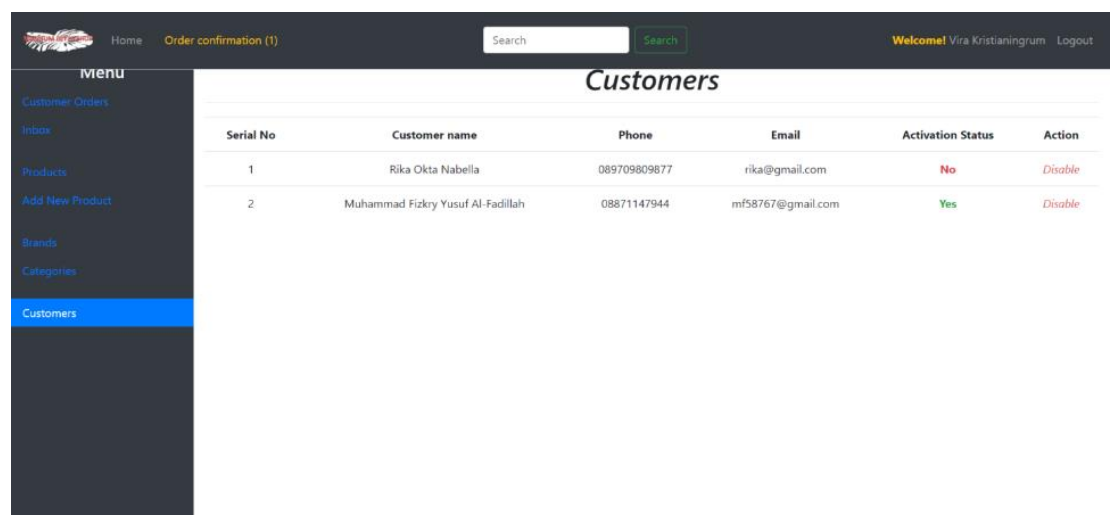

Gambar 12. Screenshot Halaman Data Customers

5. Tampilan Halaman Menu Inbox

Customer memiliki kesempatan untuk menanyakan atau berkomentar tentang proses transaksi di website penjualan ikan cupang ini. Jadi, setelah customer mengirimkan pesan nya, makan akan di kirim ke admin lalu ditampilkan di menu inbox seperti dibawah ini. Admin dapat membalas pesan dari customer melalui alamat email yang tercantum. 


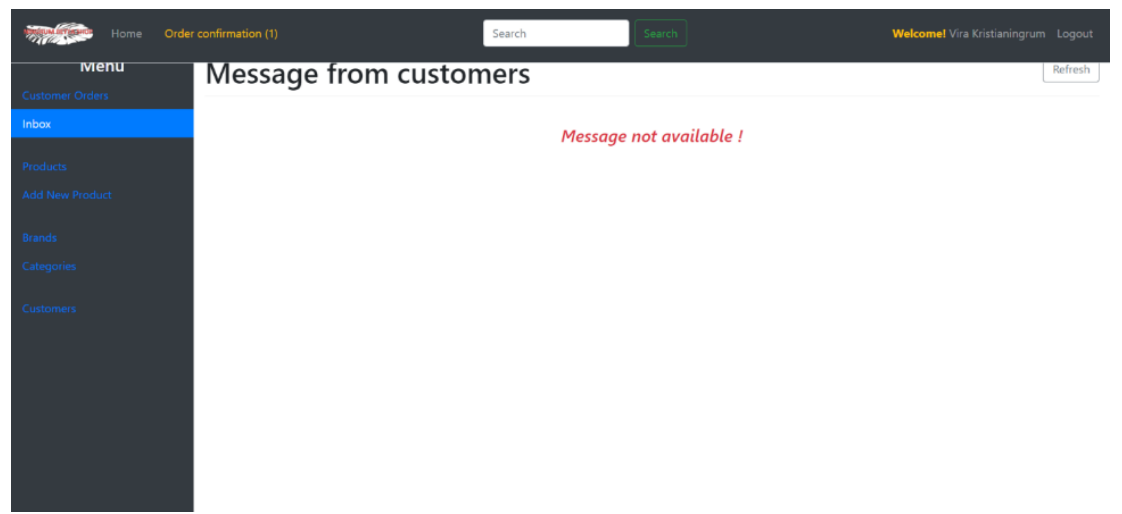

Gambar 13. Screenshot Halaman Inbox

6. Tampilan Halaman Menu Add New Product

Jika admin ingin menambahkan ikan cupang yang mau dijual, maka dapat melakukan nya di halaman ini.

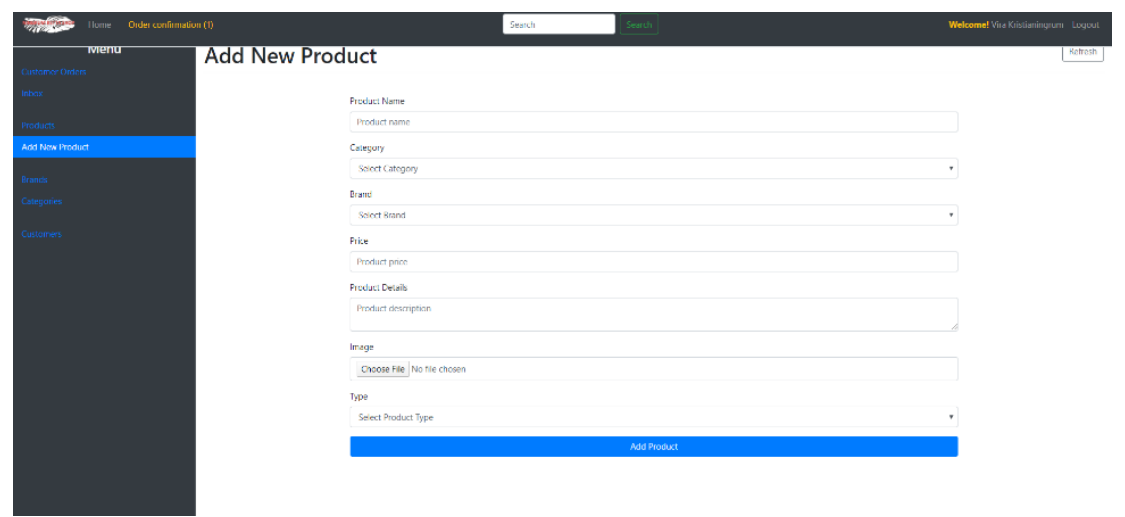

Gambar 14. Screenshot Halaman Add New Product

7. Tampilan Halaman Home

Saat pertama customer membuka website ini, maka tampilan pertama nya adalah halaman utama seperti dibawah ini yang dihadapkan dengan seluruh produk yang dijual. Dan juga terdapat menu untuk cutomer mengakses ke halaman lainnya. 


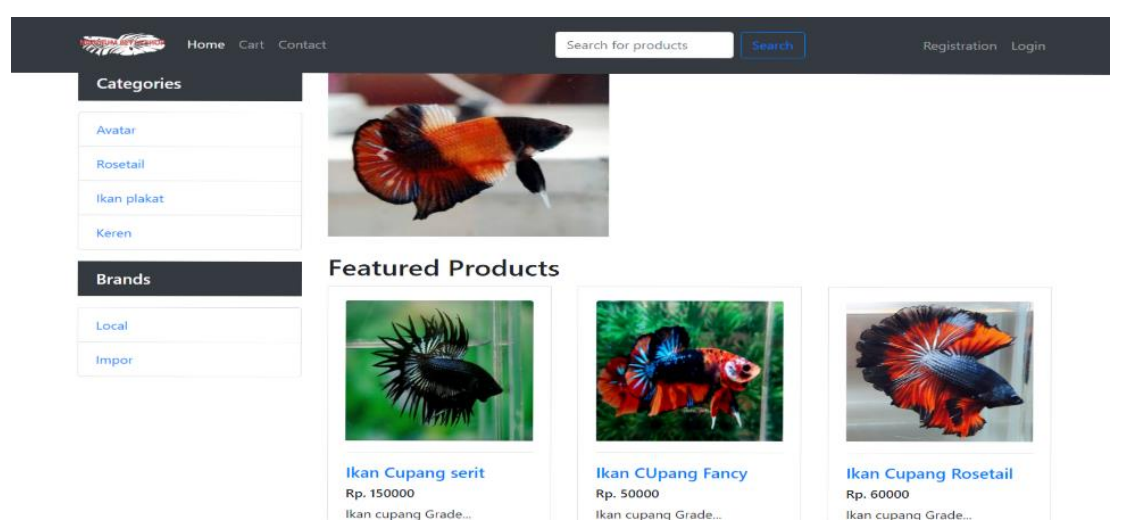

Gambar 15. Screenshot Halaman Utama

8. Tampilan Halaman Form Registrasi Customer dan Form Login Customer Sebelum dapat melakukan transaksi pembelian, customer diharuskan mendaftar dengan mengisi form yang tersedia. Sedangkan untuk customer yang telah terdaftar, dapat login dengan memasukkan username dan password yang sesuai. Lalu di enskripsi dengan database.

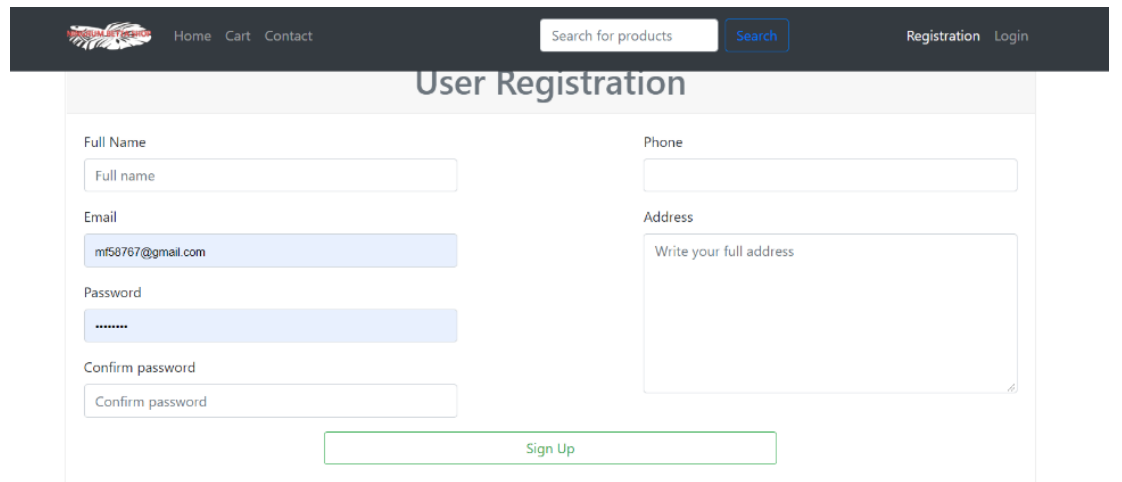

Gambar 16. Screenshot Halaman Form Registrasi Customer

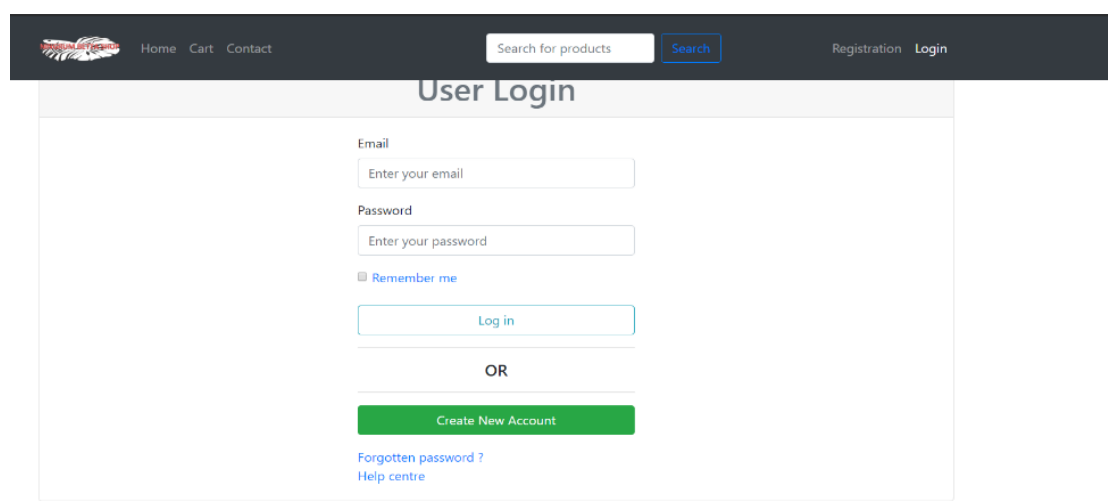

Gambar 17. Screenshot Halaman Form Login Customer 
9. Tampilan Halaman Cart

Pada halaman keranjang belanja, akan menampilkan daftar ikan yang telah dipilih oleh customer. Jika customer sudah yakin, maka akan melanjutkan ke proses pembayaran dengan memilih Customer Shopping. Namun jika customer tidak yakin, maka akan di biarkan lalu dipertimbangkan kembali. Tapi jika tidak jadi memilih, makan customer dapat membatalkan atau menghapus nya dari daftar keranjang belanja.

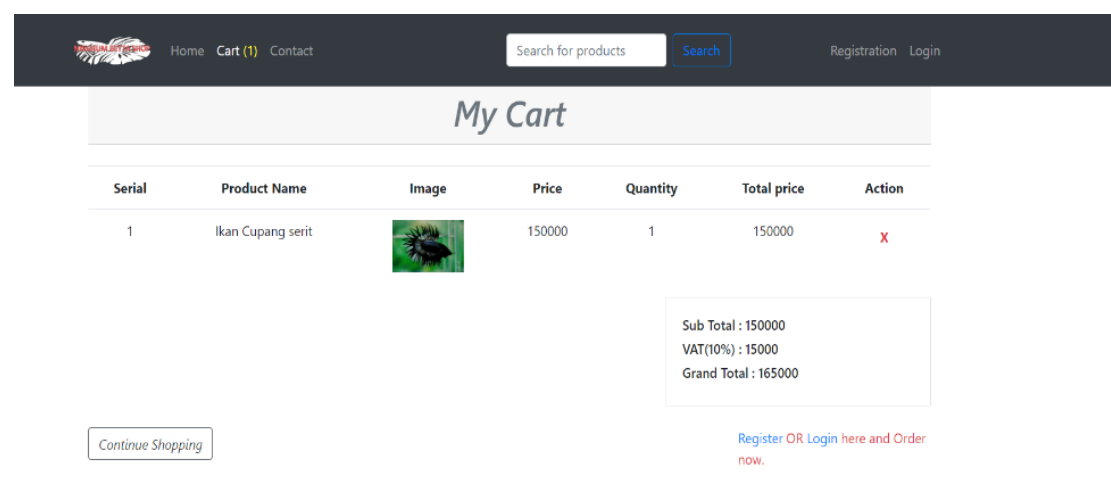

\section{Gambar 18. Screenshot Halaman Keranjang Belanja}

\section{KESIMPULAN DAN SARAN}

\section{Kesimpulan}

Dari hasil analsisi pada Perancangan Website Penjualan Ikan Cupang ini dibuat dengan metode pemodelan UML (Unified Modelling Language), ERD (Entity Relation Diagram) dan MySQL sebagai penyimpanan database yang dikoneksikan dengan Xampp. Lalu dari perancangan User Interface, menghasilkan halaman admin yang hanya dapat di akses dan dikelola oleh admin. Diantaranya ada menu halaman utama admin, menu customers orders, product, data customers, dan inbox. Sedangkan untuk customers dapat mengakses halaman utama website, halaman registrasi dan login, keranjang belanja, detail produk, pemesanan, dan mengirim pesan ke kontak penjual. Dengan adanya website ini, menjadi memudahkan customers dan juga penjual untuk melaksanakan transaksi jual beli ikan cupang yang dapat di akses dimana saja selama 24 jam. Serta bisa melakukan pemesanan tanpa membuat konsumen datang langsung ke toko penjual ikan cupang untuk membuat lebih efisien dan efektif dalam proses jual beli.

\section{Saran}

Penulis menyadari bahwa dalam pembuatan laporan dan website yang dirancang ini masih memiliki banyak kekurangan, dan dapat menjadi bahan pembelajaran untuk penelitian selanjutnya. Untuk pengembangan lebih lanjut, diharapkan dapat membuat 
tampilan website lebih untuk menarik calon pelanggan, dan menawarkan penjualan yang lebih banyak produk pendukung dari ikan cupang. Lalu dalam proses transaksinya bisa lebih dikembangkan supaya beragam.

\section{DAFTAR PUSTAKA}

Alan Dennis, Barbara Haley Wixom, David Tegarden. (2015). Systems Analysis \& Design An Object-Oriented Approach with UML. Danvers: John Wiley \& Sons, Inc.

Andi Ridho Rachman, Beny, E. F. (2017). Perancangan E-Commerce Berbasis Website Pada Toko Mirabella Batik Jambi. PROCESSOR, 12(2), 1102-1117.

George, J. F., \& Valacich, J. S. (2016). Modern Systems Analysis and Design (8th ed.). New York: Pearson.

Haerulah, E., \& Ismiyatih, S. (2017). Aplikasi e-commerce penjualan souvenir pernikahan pada toko " XYZ .” Jurnal Prosisko, 4(1), 43-47.

Hasugian, P. S. (2018). Perancangan Website Sebagai Media Promosi Dan Informasi. Journal Of Informatic Pelita Nusantara, 3(1), 82-86.

Johan Rishamdani, Aghus Sofwan, R. R. I. (2013). Perancangan Website E-Commerce Penjualan Ikan Karang. 1-7.

Martina Seidl, Marion Scholz, Christian Huemer, Gerti Kappel. (2014). UML @ Classroom: An Introduction to Object-Oriented Modeling. Heidelberg: dpunkt.verlag.

Mayang Sari, Hasanuddin, R. A. (2018). Pengenalan Ikan Cupang (Betta Fish) Menggunakan Augmented Reality. Jtiulm, 1(1), 26-36.

Megumi, S. R. (2019). Ikan Cupang, Si Agresif yang Menawan. Greeners.Co. https://www.greeners.co/flora-fauna/ikan-cupang-si-agresif-yang-menawan/

Muhamad Ridho Ramdoni, Sri Setyaningsih, E. T. T. (2014). APLIKASI PENJUALAN IKAN AIR TAWAR ONLINE (Studi Kasus : Bintang Ikan ). 1-8.

M. Niranjanamurthy, N. Kavyashree, S. Jagannath, and D. Chahar. (2013). Analysis of e-commerce and m-commerce: advantages, limitations and security issues. International Journal of Advanced Research in Computer and Com- munication Engineering: vol. 2, no. 6.

Rachman Andi, R., Beny, \& Fernando, E. (2017). Perancangan E-Commerce Berbasis Website Pada Toko Dunia Palembang. Jurnal Ilmiah Processor, 12(2), 1102-1117. 
Rachmat Destrana, Didin. (2019). Analisis dan perancangan e-bisnis dalam budidaya dan penjualan ikan cupang menggunakan metodelogi overview. Jurnal Teknik Informatika (JIKA) Universitas Muhammadiyah Tangerang.

Salehi, F., Abdollahbeigi, B., Langroudi, A. C., \& Salehi, F. (2012). The Impact of Website Information Convenience on E-commerce Success of Companies. Procedia - Social and Behavioral Sciences, 57, 381-387. https://doi.org/10.1016/j.sbspro.2012.09.1201 udah

Saibaba, G., \& Prasanth Vaidya, S. (2018). Developing an userfriendly online shopping web-site. Indonesian Journal of Electrical Engineering and Computer Science, 12(3), 1126-1131. https://doi.org/10.11591/ijeecs.v12.i3.pp1126-1131

Rosenblatt, H. J., \& Tilley, S. (2016). System Analysis and Design. Boston: Cengage Learning.

Putri, Tiara Nabila, Rifnaldi, and Surmiyanti. (2019). Penggunaan Bahasa Pemrograman PHP Dan MySQL Sebagai Penunjang Sistem Informasi Persediaan Dan Penjualan Secara Online. 5 (2): 61-66. 